\title{
Strategy For Overcoming Gadget Addiction Through Christian Education In Medan
}

\author{
Lestari Perangin-angin \\ \{lestarinangin2016@gmail.com\} \\ Postgraduate Program, Pelita Kebenaran School of Theology
}

\begin{abstract}
The aim of this study is to suggest a strategy derived from Christian religious education to children with gadget addiction in the city of Medan, the capital city of the province of North Sumatra, Indonesia. This paper takes data from direct interviews with children and parents at several points in the city of Medan, as well as data from relevant agencies and literature studies. This data is from 2017 to 2019. Data at the provincial level is also shown in this paper as a comparison. The negative impact due to gadget addiction on children in the city of Medan, if seriously anticipated by parents, educators, and all relevant government institutions, will minimized the community's problems in the future.
\end{abstract}

Keywords: Strategy, Gadgets Addiction, Christian Religious Education.

\section{Introduction}

Gadgets such as Android mobile products, tablet PCs, and similar devices integrated with the internet have caused children and adults to become addicted. The phenomenon of gadget addiction has ruined normal human life. Addiction to gadgets can be likened as a tsunami that cannot be restrained and causing mass casualties. The author observes the phenomenon of gadget addiction in children in the city of Medan, the capital of North Sumatra Province, Indonesia. Nowadays, it is very easy to find children playing gadgets in public, whether in public transportation and anywhere else along with parents who are active whom are not worrying whether their children will interfere with their activities.

The author found several problems in children who are addicted to gadgets, namely: (1) children become more angry and hysterical, especially if disturbed or stopped when using gadgets, (2) when the internet quota on the gadget runs out, the child goes to the internet cafe without remembering time, even in the early hours, (3) children skip school to satisfy their desire to play the internet, because some schools still apply regulations prohibiting students from carrying mobile phones to schools, (4) children's activities become disorderly, undisciplined, even forget to eat and sleep late, (5) children become spoiled enjoying the pleasures of entertainment presented by various applications in gadgets, do not like to work hard, are lazy to move, (6) children no longer think about what's important such as school assignments and helping parents, (7) children behave disrespectfully towards their parents, (8) children see pornographic content that enters their social media accounts, (9) Children no longer obey and diligent in conducting worship, (10) parents are increasingly burdened with the cost of buying internet quota and children's behavior is getting worse.

This study focuses on the behavior of children who are addicted to gadgets, using behaviorism personality theory as proposed by the psychologist B.F. Skinner who views human 
behavior as being largely composed of responses called the operant behavior. The consequences or results of behavior will determine the tendency of the organism to repeat or stop its behavior in the future. If it is pleasant or beneficial, the organism will repeat or maintain its behavior. Conversely, if the results of behavior are unpleasant or detrimental, then the behavior by the organism will be stopped and not repeated. The next theory used is a multilevel needs theory proposed by psychologist Abraham Maslow, especially in the part of the need for selfactualization. One's self-actualization comes from the individual's desire to be the person who is in accordance with his desires and potential.

Internet addiction theory put forward by Kandell defines internet addiction as a psychological dependency on the internet no matter what type of activity is carried out during $\log$ in. With interpretation based on Kandell's theory the author argues that an indication of someone being addicted to gadget is not because of playing games or being active on social media, but because the person feels that he cannot live without a gadget, feels that something is missing he cannot use his gadget. Running out of internet quota and running out of battery power makes such people nervous, headaches caused by having no signal are signs of gadget addiction on a low scale. Addiction theory according to Gerald May explained that addiction is a situation where impulses, obsessions or preoccupations enslave one's will and desire. Attachment to a substance, thoughts, attitudes or behavior that is sustainable, both consciously and unconsciously, even though the person knows that this is damaging to his/her health.

\section{Research Method}

This study focuses on gadget addiction in children in the city of Medan. This research is descriptive in that it seeks to describe, collect, compile, and interpret existing data, followed by examining factors related to the phenomenon of gadget addiction in the city of Medan. Data is taken from interviews conducted with children and parents, data from relevant agencies, and related literature. The technique used in interviews with children and parents in the city of Medan is a simple random sampling technique. This study uses the behaviorism personality theory proposed by Skinner, the multilevel needs theory proposed by Maslow, the theory of internet addiction proposed by Kandell and the theory of addiction by Gerald May.

\section{Results}

Children in this era are called Digital Natives with the specifications: (1) Identity, wanting to show the world that they exist; (2) Privacy, they tend to be open; (3) Control and Freedom, they do not want to be regulated; (4) Learning Process, actively accessing Google and information search engines. While parents are classified as Digital Immigrants, namely users of SMS and telephone services, who do not care about cyberspace and need the help of children (Digital Natives) to understand using the internet. Percentage of Children Aged 5-6 Years who Access the Internet according to

Table 1. Regency/City and Gender in North Sumatra, 2017 


\begin{tabular}{|c|c|c|c|}
\hline Regency/City & Male & Female & Male and Female \\
\hline$(1)$ & $(2)$ & (3) & $(4)$ \\
\hline Nias & 0,00 & 0,00 & 0,00 \\
\hline Mandailing Natal & 0,00 & 1,02 & 0,58 \\
\hline Tapanuli Selatan & 0,00 & 0,00 & 0,00 \\
\hline Tapanuli Tengah & 1,96 & 0,85 & 1,44 \\
\hline Tapanuli Utara & 0,00 & 1,40 & 0,65 \\
\hline Toba Samosir & 2,05 & 0,00 & 0,97 \\
\hline Labuhan Batu & 0,00 & 0,00 & 0,00 \\
\hline Asahan & 0,00 & 0,00 & 0,00 \\
\hline Simalungun & 1,13 & 0,00 & 0,56 \\
\hline Dairi & 0,00 & 0,93 & 0,49 \\
\hline Karo & 1,11 & 1,18 & 1,15 \\
\hline Deli Serdang & 2,72 & 1,44 & 2,07 \\
\hline Langkat & 0,00 & 0,00 & 0,00 \\
\hline Nias Selatan & 0,00 & 0,00 & 0,00 \\
\hline Humbang & 0,00 & 0,00 & 0,00 \\
\hline Hasundutan & 0,63 & 0,00 & 0,31 \\
\hline \multicolumn{4}{|l|}{ Pakpak Barat } \\
\hline Samosir & 0,00 & 0,00 & 0,00 \\
\hline Serdang Bedagai & 0,00 & 0,00 & 0,00 \\
\hline Batu Bara & 0,00 & 0,00 & 0,00 \\
\hline Padang Lawas Utara & 0,00 & 0,00 & 0,00 \\
\hline Padang Lawas & 0,00 & 0,00 & 0,00 \\
\hline Labuhan Batu & 0,91 & 1,21 & 1,05 \\
\hline Selatan & 0,00 & 0,00 & 0,00 \\
\hline Labuhan Batu Utara & 0,00 & 0,00 & 0,00 \\
\hline Nias Utara & 0,00 & 0,00 & 0,00 \\
\hline Nias Barat & 1,45 & 8,49 & 4,62 \\
\hline Sibolga & 4,03 & 2,30 & 3,06 \\
\hline Tanjung Balai & 7,40 & 2,47 & 5,02 \\
\hline Pematang Siantar & 2,09 & 17,50 & 7,76 \\
\hline Tebing Tinggi & 3,04 & 6,90 & 4,83 \\
\hline Medan & 2,63 & 3,88 & 3,22 \\
\hline Binjai & 0,00 & 5,14 & 2,65 \\
\hline $\begin{array}{l}\text { Padang Sidempuan } \\
\text { Gunung Sitoli }\end{array}$ & 0,00 & 0,00 & 0,00 \\
\hline
\end{tabular}

Table 2. Percentage of Children Aged 7-17 Years Accessing the Internet by Purpose of Accessing in Medan City, 2017

\begin{tabular}{lc}
\hline \multicolumn{1}{c}{ PURPOSE } & $\mathbf{\%}$ \\
\hline Attaining information/news & 38,98 \\
Doing homework & 76,13 \\
Sending/receiving email & 9,20 \\
Social media/Social network & 62,91 \\
Entertainment & 60,99 \\
Other & 00,0 \\
\hline
\end{tabular}

Children in the age group of 5-6 years use the most gadgets for entertainment, while children in the 7-17 year age group use the most gadgets to do school work and social media. 
Data on the percentage of the purpose of using gadgets for school assignments is still higher than social media, but the results of interviews indicate that for longer periods of usage, children use gadgets longer for social media such as Facebook, watching Youtube and playing games.

Answers collected from interviews with children include: (1) Children cannot do without gadgets (mobile phones), gadgets are considered to be the most enjoyable entertainment than television (2) Parents allow the use of gadgets on school days provided that school assignments must be completed first, (3) The use of gadgets on school days 1-2 hours or more, on school holidays free to use gadgets for long, even to sleep late at night, (4) According to dangerous children of gadgets are naked videos and viral news that should be for adults. Other things other than the use of gadgets, but perhaps related are children who are depressed by the number of school assignments, often scolded by parents, so that gadgets become a kind of place to escape and get entertained.

The bad effects of gadgets that lead to greater danger are: (1) Children can become victims of predators and bullying, (2) Disrupted brain effects, (3) Lazy to move, disturbed body motor functions, (4) Reduced socialization, lack of socialization in the real world, (5) Addiction, (6) Slow thinking, (7) Exposure to pornography.

In this study the authors proposed a strategy to overcome gadget addiction based on Christian education, namely Bible teaching. The Christian education strategy has the main goal, namely that everyone knows Christ and has a new way of life, good and right according to the teachings of the Christian faith.

The strategy that the author proposes to be implemented in the family is: (1) Repeatedly teaching the Word of God and praying in the family regularly and continuously filling the child's mind with truth. The target is children to know God as the owner of his life. Bad influences that enter the minds of children through gadgets must be replaced and omitted or at least given light by parents with Biblical perspective. If parents are busy, family members who live together in the house must continue to carry out worship and family prayers, scheduled in turns. (2) Worship is made as a fun activity. Build a habit of bringing children to an event that is worship, until the child is used to and really enjoys it. (3) Practice good habits every day. Sitting together between parents and children every day talking about anything and store gadgets during the time to chat is one example. (4) Openness. Discuss any issues in depth including those that are confidential and considered taboo, such as sex problems, family financial difficulties, and so on. (5) Love and not anger. Parents help children with compassion and not anger, until children can change from being addicted to gadgets. Parents must add patience and ingenuity if the child has been indicated to be addicted to a gadget, (6) Transferring the child's focus, transferring children's activities to other positive activities, and by assisting parents.

Strategies in school by teachers: (1) Give examples of wise use of gadgets, (2) Encourage students to be interested in opening sites that encourage interest in achievement and character building. All of these strategies come from Christian teaching about parenting in the family that must teach the Word of God repeatedly to plant a good foundation of character until the child is strongly rooted and grows in the right way of life. Even the chronic level of addiction to gadgets can be cured by implanting truth in the child's mind and constantly rearranging habits in every day family life.

\section{Conclusion}


Leaving children unattended, delays in disciplining children, lags in providing assistance to children who are addicted to gadgets, assuming that gadget-playing for children is not a problem will have a negative impact on children's behavior, like a time bomb ready to explode at any time. Every second, the danger is approaching children through gadgets, negative changes in children's behavior is very fast and increasingly felt by parents.

Parents being stressed and not knowing what to do when seeing the behavior of children addicted to gadgets will not solve the problem. Whether they like it or not, parents must force themselves to act, give time and attention and prayer for their children who are attacked daily by the negative influence of gadgets. The strategy proposed by the author to overcome gadget addiction in children in the city of Medan based on Christian Education consists of six steps as follows. (1) Repeatedly teach the truth from the scriptures, (2) Have fun worship, (3) Practice good habits every day, (4) Openness, (5) Love and not anger, (6) Transfer of children's focus. However, as good as any strategy is, it will not be useful if not implemented immediately.

\section{References}

[1] E. Koeswara : Teori - teori Kepribadian. PT. Eresco, Bandung, (1991).

[2] Nyi Mas Diane Wulansari : Didiklah Anak sesuai Zamannya. PT. Visimedia Pustaka, Jakarta (2018).

[3] Chou, C., Condron, L., \& Belland, J.C. : A review of the research on Internet addiction, Educational Psychology Review, 17 (4), pp.363-388. (2005).

[4] David Allen, M.D. : Cara Memulihkan Karakter. pp.121. Yayasan Penerbit Gandum Mas, Malang (2001).

[5] Thaswin Eddy,S.Si., Aida Meimela, SST., Viane Dorthea Tiwa, SST. : Profil Anak Sumatera Utara 2018, pp. ix. Kerjasama Dinas Pemberdayaan Perempuan dan Perlindungan Anak Provinsi Sumatera Utara dengan Badan Pusat Statistik Provinsi Sumatera Utara, Medan (2018).

[6]Timotius Adi Tan : Smart Parenting. PT. Elex Media Komputindo, Jakarta (2009).

[7] Elizabeth T. Santosa : Raising Children In Digital Era. PT. Elex Media Komputindo, Jakarta (2015).

[8]Paul Meier,M.D., Jan Meier, Cheryl Meier : Menjadi Remaja yang Bahagia. ANDI, Yogyakarta (2001).

[9]Andreas Agus W., M.A. : Anak Muda Berteriak WOWW!!!. Yayasan Diakonia Internasional, Bandung (2010).

[10]Ir. Jarot Wijanarko : Mencetak Anak Juara Kehidupan. Yayasan Pulihkan Indonesia, Jakarta (2015). 